\title{
Genealogija prostora v bibličnih besedilih: Stvarjenje
}

\author{
The Genealogy of Space in Biblical Texts: The Creation
}

Povzetek: Problemski okvir prispevka so prostorske podobe v svetopisemskih pripovedih o stvarjenju. V analizi je bilo obravnavano besedilo razčlenjeno v tri module: modul, ki vsebuje duhovniški zapis o stvarjenju, sledi modul s starejšim jahvističnim poročilom, v zadnjega pa je vključena pripoved o vesoljnem potopu. Analiza je potrdila bogastvo prostorskih podob, ki besedilu niso zgolj okras, marveč so pogosto uporabljene kot nosilci vsebin, v katerih se kaže dramatičnost premen v odnosu med človekom in transcendenco. Primerjava ugotovljenih prostorskih podob z arhitekturno arhetipsko matrico sakralnega je potrdila prisotnost nekaterih arhitekturnih arhetipskih prvin. Te razkrivajo nova obzorja razumevanja istovetnosti krščanskega sakralnega prostora pa tudi sakralnega prostora drugih »religij knjige«.

Ključne besede: arhitektura, sakralni prostor, arhitekturni arhetip, Sveto pismo, stvarjenje, prostor

\begin{abstract}
The framework of the problem addressed in the contribution is spatial images in biblical narratives of the Creation. In the analysis, the discussed text is broken down into three sections; a section concerning the priestly narrative of the Creation, followed by a section with the earlier Yahwist narrative, while the last section discusses the narrative of the universal flood. The analysis confirmed the richness of spatial images, which are not just ornaments to the text, but are often used as bearers of content in which the dramatic nature of the alternations in the relationship between man and transcendence is reflected. Comparison of the established spatial images with the architectural archetypal matrix of the sacral confirmed the presence of a number of architectural archetypal elements. These reveal new horizons of understanding the identity of the Christian sacral space, as well as the sacral space of other "religions of the Book".
\end{abstract}

Key words: architecture, sacral space, architectural archetype, the Bible, the Creation, space

\section{Uvod}

Živimo v času, ki se utaplja v deročem toku sporočilnosti. Postajamo nemočni brodolomci sredi razdivjanega vodovja lastne ustvarjalnosti. V kakofoniji deliričnih poskusov zgodbičarjev vse težje prepoznavamo velike 
zgodbe, na katere se usedajo nanosi informacijskega mulja. Ta sicer s svojo motnjavo otežuje preglednost, a nikakor ne more zmanjšati sporočilne živosti velikih zgodb, osvobojenih sleherne novičarske atraktivnosti. Eno takih velikih zgodb, ki se vedno znova s presenetljivo klenostjo in domala nepregledno pomensko kompleksnostjo upira informacijskemu cunamiju, nosijo biblična besedila. Z njo se istovetijo religije, kot so judovstvo, krščanstvo in islam. »Usodno privlačna« je zaradi tematiziranja zapletenih vsebin, povezanih s človekovim spraševanjem o bistvu in smislu njegovega bivanja. Vsaj na tej točki zadene njen mik v živo tudi arhitekturo. Ta se osmišlja s tem, da daje človekovemu bivanju žlahtno prostorsko resonanco, ko njegove prostorske probleme navdihnjeno preoblikuje v prostorske kakovosti. V tako razumljenem poslanstvu se arhitektura pravzaprav sooča z zase edino resnično enigmo - z oblikovanjem prostora človekovega sobivanja s transcendenco. Skupno osišče obeh realnosti, religije in arhitekture, je človek. Človek je po eni strani v svoji fizični realnosti vklenjen v materialnost lastnega bivanja, po drugi pa se v svojem metafizičnem nemiru vedno znova steguje onkraj teh obzorij.

Problemsko jedro pričujočega poskusa bodo tako prostorske podobe, ki so se piscem in redaktorjem bibličnih besedil zdele učinkovite pri približanju nekaterih vidikov nedoumljivega božjega delovanja v stvarstvu tudi najbolj preprostemu človeku. Ob pozornejšem branju bibličnih besedil ni mogoče spregledati relativne pogostosti in raznolikosti takih prostorskih podob. Njihova abstraktnost (edenski vrt, Ezekielov tempelj ali nebeški Jeruzalem) oziroma konkretnost (na primer jeruzalemski tempelj) sta za zastavljen prikaz nepomembni, saj je v ospredju namera podrobneje proučiti njihovo naravo, notranjo strukturo in kakovost, $v$ kateri so sestavljavci bibličnih besedil prepoznavali moč posredovanja kompleksnih teoloških sporočil.

V metodološkem pogledu je raziskava zasnovana v dveh korakih. Prvi se nanaša na odkrivanje prostorskih podob v bibličnih besedilih in ugotavljanje njihovih prostorskih oziroma arhitekturnih značilnosti z literarnokritično metodo in metodo arhitekturne analize. Drugi pa se po logiki primerjalne analize nanaša na primerjanje teh značilnosti z modelom arhitekturne arhetipske matrice sakralnega kompleksa. (Debevec 2011, 202-273) Korpus bibličnih besedil torej ni zgolj teološki temelj religij oziroma zakladnica človekove modrosti, temveč je ob siceršnji skromnosti antičnih teoretskih besedil o arhitekturi tudi dragoceno polje, v katerem 
more arhitekturna teorija, osmišljena z vedno vnovičnim prevpraševanjem temeljev lastne istovetnosti, odkrivati pomembne odgovore. Svojevrstno osišče takega prepletanja teološke misli in senzibilnosti za umetnost je na mariborski enoti Teološke fakultete utelešal prof. Rafko Vodeb. V svoji svetovljanski širini, pridobljeni ob opravljanju odgovornih služb v tujini, se je dobro zavedal nevarnosti gluhote za lepo. Kot predavatelj cerkvene umetnosti na papeški Urbaniani in oddelku Teološke fakultete v Mariboru je to gluhoto požrtvovalno »zdravik.

Končno, a zato nič manj pomembno, je proučevanje biblične interpretacije temeljnih prvin našega bivanja, med katerimi zavzema prostor domala osrednje mesto, nezamenljivi fundament medreligijskega dialoga, v katerem se bistri meja med univerzalnim in partikularnim ter se tako kažejo možne smeri žlahtnega sobivanja. Na področju sakralne arhitekture spada med učinkovita orodja prepoznavanja takih prvin model arhitekturne arhetipske matrice sakralnega. $Z$ njegovo pomočjo se nam v raznolikosti sakralnih kompleksov razkrivajo skupne prostorske značilnosti, ki jih človek prepoznava kot učinkovit okvir žlahtnjenja njegovega odnosa s transcendenco (Debevec 2013, 50).

Omejen obseg zastavljenega prikaza narekuje vsebinsko zamejitev. Tako bodo v nadaljevanju obravnavane prostorske prvine, ki jih prepoznavamo v bibličnih zapisih o stvarjenju. Gre za besedilo 1 Mz 1,1-3,24. Podrobni poznavalci bibličnih besedil ga pripisujejo dvema viroma. Mlajšemu duhovniškemu je pripisano besedilo $1 \mathrm{Mz}$ 1,1-2,4, del besedila $1 \mathrm{Mz} 2,4 \mathrm{~b}-25 \mathrm{pa}$ starejšemu jahvističnemu. Izročili se med seboj v marsičem razlikujeta, a sta hkrati izraz miselnih obzorij Izraelcev med devetim in petim stoletjem pr. Kr.

\section{Prostorske reminiscence v duhovniškem zapisu o stvarjenju}

Že prvi stavek Svetega pisma, „V začetku je Bog ustvaril nebo in zemljo« ( $1 \mathrm{Mz}$ 1,1; po vsebini domala identično tudi Jahvist v 1 Mz 2,4b), zadene v samo srčiko dveh človeku povsem samoumevnih, a hkrati izmuzljivih stvarnosti: časa in prostora. Pokaže namreč na nepremostljivo kakovostno razliko med Stvarnikom, bivajočim onkraj sleherne človeku predstavljive kategorije, in stvarstvom, vpetim v strukturo časa in prostora. Stvarstvo kot 
materija je v svojem obstoju nujno pogojeno s prostorom (Muhovič 1996, 5). Materija napolnjuje prostor ter ga $z$ gostoto in načinom razporeditve členi. Tako dobi prostor prepoznaven izraz. V obravnavanem stavku je ta edinstveni zliv prostora-materije opredeljen $z$ dvodelnostjo neba in zemlje. Dualnost kaže na izrazito človeško perspektivo doživljanja stvarstva, saj je človeku zemlja bolj ali manj obvladljivi milje njegovega bivanja, medtem ko mu je nebo tuja in v misterij zavita realnost. Da bi prostor in materija zaživela v součinkovanju, je potreben povsem nov pogoj. To je čas (Muhovič 1996, 6). Čas, razumljen kot abstraktni kontinuum, ki določa zaporedje dogodkov součinkovanja prostora in materije v danem kraju (McGraw-Hill 2007), šele na ta način vstopa v človekovo čutno-zaznavno obzorje. Izraz »v začetku« je torej mogoče razumeti kot stvarnikovo sproženje stvarstvu lastnega časa, da bi oživil interakcijo med ustvarjenim prostorom in ustvarjeno materijo. Judovska kultura je zelo zgodaj prepoznala moč časa in dala v predstavljeni dihotomiji časa in prostora prednost času ter tako vzpostavila edinstvenost njene istovetnosti. »Zdi se, " pravi znani judovski rabin Heschel, »da je čas, ko gledamo resničnost in so naše duše očarane nad predmeti v prostoru, v neprestanem gibanju. Ko se začnemo zavedati, da so predmeti $v$ prostoru tisti, ki se neprestano gibljejo, spoznamo, da je čas tisti, ki nikoli ne poteče, in da je svet prostora tisti, ki se giblje skozi neskončno prostranstvo časa.« $(2013,95)$

Ob povedanem se postavlja skoraj samoumevno vprašanje, zakaj sploh obravnavati prostorske prvine v bibličnih besedilih. Enega izmed odgovorov najdemo v mehanizmu součinkovanja znotraj že predstavljene trojice čas-prostor-materija. Pokaže nam, da čas šele v interakciji s prostorom-materijo vstopa v človekovo čutno-zaznavno obzorje. Prostor-materija se torej pokaže kot nezamenljiva resonančna posoda, brez katere bi ostal čas v svoji abstraktnosti, podobno kot prostor ob odsotnosti materije, zunaj človekovega zaznavnega obzorja. Čas razkriva na minljivi materiji sledi bivanja, rasti, zorenja, staranja in razkroja. Slednje lepo prikaže besedilo $1 \mathrm{Mz}$ 1,3-2,4. V njem namreč stvarjenje ni razgrnjeno pred bralca kot nekontrolirana erupcija nepredstavljive stvarnikove moči, temveč kot premišljeno strukturirana stvarjenjska dejanja v sedmih dnevnih časovnih intervalih. Da bi veličina stvarjenjskih dejanj simbolno popolnega (zaokroženega) sedemdnevnega cikla zaživela v vsem svojem sijaju, prinaša 1 Mz 1,2 nekaj pomenljivih lastnosti prvobitnega stvarstva. Gre za pustost, praznino in temo. Prvi dve, v hebrejskem izvirniku tóhu in bóhu, v dobesednem 
prevodu puščava in praznina (SPJ 1014, 47), je takratni človek dobro poznal, saj se je s pregovorno divjostjo, neurejenostjo in pustostjo puščave stalno srečeval. Pustost in praznost nista kakovosti, s katerima bi Stvarnik opisoval svoje stvaritve. Prej nakazujeta človekovo središčno vlogo v stvarstvu, preko katere ga osmišlja. V luči stvarnikove popolnosti in iz nje izhajajoče mimobežnosti sleherne kategoričnosti je namreč stvarstvo nujno popolna uresničitev stvarnikovega déja. Tudi tema je stanje, ki človeku bistveno zoži kakovost doživljanja prostora na njegove predvsem tipne sposobnosti. V tem človeku še zelo tujem, domala divjem prvobitnem stvarstvu pa 1 Mz 1,2 že pokaže na neko bistveno kakovost, na pomirjujočo prisotnost božjega, saj nad surovostjo prvobitnega stvarstva veje »Božji duh«.

Stvarjenje časa in prostora, ki nam ga razkriva prvi stavek Svetega pisma, vzpostavlja najširši okvir, znotraj katerega more zaživeti odnos med človekom in transcendenco. $\mathrm{V}$ pozornejšem opazovanju prostorskih reminiscenc nadaljnjega opisa stvarjenja (1 Mz 1,3-2,3) prepoznavamo poteze $s$ premišljenimi koraki postavljenega mogočnega odra, na katerem se bo odvijala drama človekove razpetosti med njegovim tesnim prijateljstvom s Stvarnikom in nikoli ugaslo skušnjavo v njem streči zgolj lastnim željam. Kar najprej opazimo, je vsebinska dihotomija stvarjenjskih dejanj v simbolni zaokroženosti sedemdnevnega cikla, pomenljivo členjenega v razmerju štiri proti tri. Razmerje je med drugim, v egipčanski kulturi (bližnji Izraelcem), razmerje stranic svetega trikotnika 3: 4:5. Omogoča namreč enostavno in natančno določitev pravega kota, izredno pomembne arhitekturne kompozicijske prvine. To razmerje pa najdemo tudi v pitagorejski matematično-glasbeni teoriji, utemeljeni na prepričanju pitagorejcev, da je temeljni princip resničnosti število (Bouleau 1963, 81-113). Pitagora (570495 pr. Kr.) je namreč odkril, da razdelitev strune strunskega instrumenta v razmerju malih celih števil, $1: 2,2: 3,3: 4$, ustvarja čiste konzonančne glasbene intervale, ki so po besedah Pitagorovega učenca Filolaja »ugodni za uho« (Muhovič 2015, 626).

Značilnost stvarjenjskih dejanj štiridnevnega modula je določitev prostorskih značilnosti omenjenega »odra«, medtem ko se stvarjenjska dejanja zadnjih treh dni nanašajo na vzpostavitev življenja na tem odru. Najprej, prvega dne (1 Mz 1,3-5), je ustvarjena svetloba. S stališča obravnave prostora gre za logičen korak. V človekovo prepoznavanje in doživljanje prostora vnaša bistvene kakovosti, kot so barve, dinamičnost in dramatično 
obogatitev njegove semantičnosti. Ločitev svetlobe od prvobitne teme in "udomačitev« teme (noč) kot antipoda svetlobi (dan) vzpostavlja ritem, z njim pa prepričljivost učinka časnosti, minljivosti.

Če moremo v stvarjenju svetlobe videti olajšanje in bistveno obogatitev človekovega doživljanja mogočnosti stvarnikovih dejanj, pa smo v stvarjenjskem dejanju drugega dne (1 Mz 1,6-8) že priča prvim »arhitekturnim« potezam. Stvarnik najprej razmeji prvobitno vodovje z obokom. Ustreznejši izraz bi bil polkupola, saj je arhaični človek prepoznaval prostorske značilnosti nebesnega svoda predvsem preko navidezne poti sonca, ki dan za dnem zarisuje lok med njegovim vzhodom in zahodom, medtem ko se mu je talna ploskev, s katere je opazoval to dogajanje, ne glede na svojo konfiguracijo kazala kot bolj ali manj pravilen krog (SPJ 2014, 47). Tako postaja nebesni svod skrajna meja človekovih čutno-zaznavnih sposobnosti in zato tudi simbol slutnje, od kod more pričakovati nedoumljive posege $\mathrm{v}$ lastno bivanje.

Tretji dan (1 Mz 1,9-13) stvarnikova stvariteljska moč poseže v vodovje pod nebesnim svodom. Iz njega prikliče kopno in tako vzpostavi temeljno doživljajsko dvojnost človekovega bivalnega prostora; trdnost in tektonsko gotovost zemlje kot nasprotje negotovosti, spremenljivosti in tokovni nepredvidljivosti morja. Z dodelitvijo rodovitnosti zemlji (1 Mz 1,11-12) ta dobi primat nad morjem. Troslojni model stvarstva (risba 1) kot plošče kopnega z nebom nad njim in podzemljem (Sheol) pod njim, prekritega s kompaktno kupolo nebesnega svoda, ki je stvarstvo varovala pred brezobličnim vodnim kaosom, je podoba antropocentričnega, za antične Hebrejce značilnega doživljanja prostora kot strogo zamejenega in hkrati brezmejne realnosti, saj se mu edini človeku vidni rob - premikajoče se obzorje - stalno izmika (Knight 1990, 175-176). 


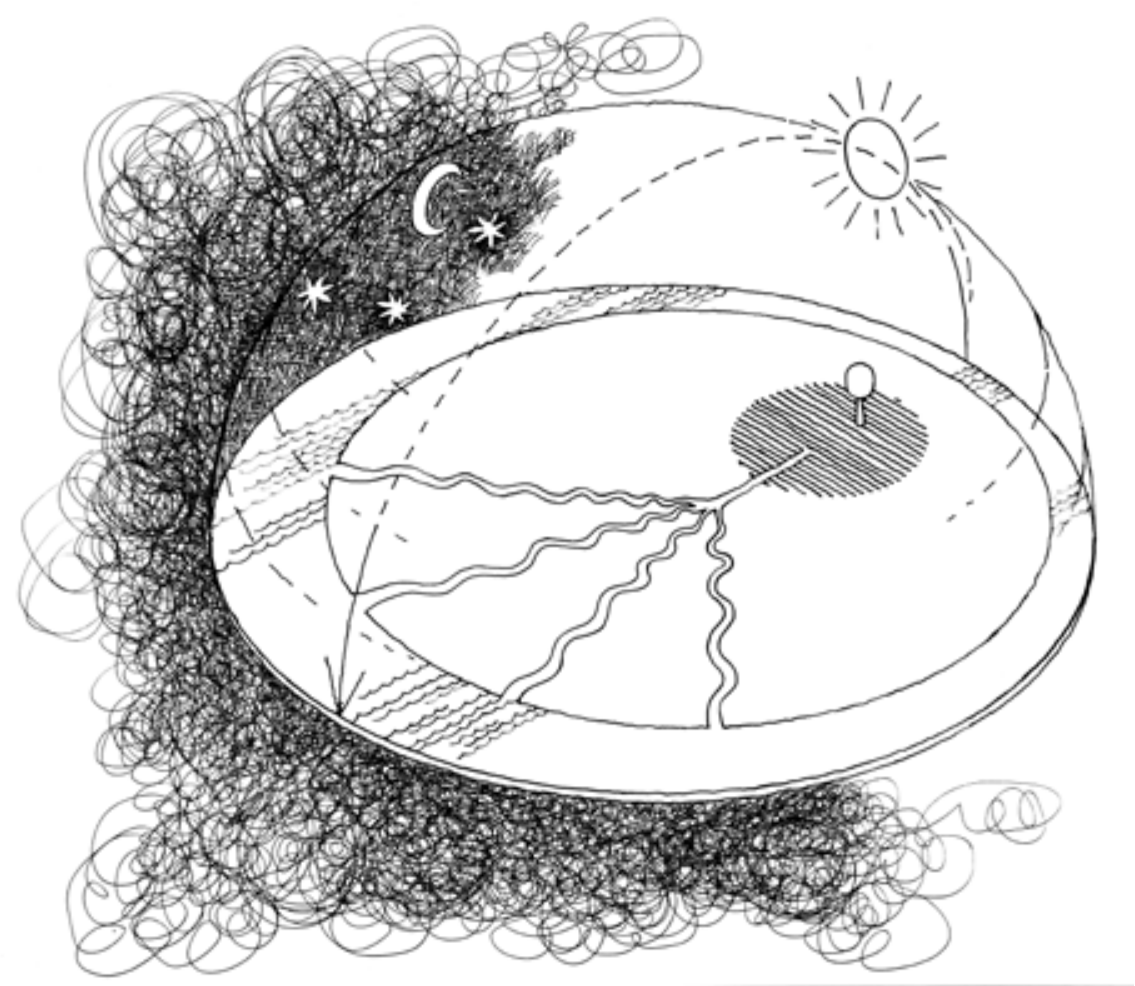

Risba 1

Četrti dan (1 Mz 1,14-19) stvarnik dokonča »arhitekturo«stvarstva, v katerem bo dominiral človek, s strukturiranjem svetlobe, prisotne v stvarstvu že od prvega dne. Svetloba dobi dve bivanjski obliki: dnevno, imenovano sonce, in nočno, ki se kaže po luni in zvezdah. S tem stvarjenjskim dejanjem je prvobitna nepredirna tema dokončno pregnana. Obe bivanjski obliki dajeta izvorni edinstvenosti svetlobe pomembne prvine, kot so pot, smer in premene (v spreminjajočih se konstelacijah zvezd in luninih menah). Slednje so učinkovita »znamenja za čase, dneve in leta« (1 Mz 1,14), saj soustvarjajo ritem in vzpostavljajo razmere, v katerih se bo človek lahko v stvarstvu orientiral ter ga tako udomačil. Navidezna pot sonca mu določa osnovno orientacijsko smer, na katero se postavi s svojim značilnim ploskim telesom. Slednje mu pokaže na to os pravokotno smer ter razmeji njegov doživljajski prostor na »spredaj« in »zadaj«. Fiziognomija človeškega telesa določa še dve ploskvi, pomembni za njegovo orientacijo v prostoru: talno ploskev, ki je konkretna in po kateri se giblje, ter navidezno, 
postavljeno v višino človekovih oči, po kateri loči »zgoraj« od »spodaj« (Butina 1982, 209-215). Prostorski okvir bivanja je tako dovršen.

Drugi, tridnevni modul stvarjenjskega cikla razgrinja, kot že rečeno, proces oživitve izoblikovanega odra (stvarstva). Pomenljivo je, da življenje vznikne najprej v vodi in v zraku (1 Mz 1,20-23), človeku najbolj izmikajočih se realnostih, ter se šesti dan (1 Mz 1,24-31) razmahne tudi po kopnem. Kot zadnji je ustvarjen človek. Z njim dobi celotno stvarstvo zaokroženost in smisel, saj sta samo predstavnika človeškega rodu mož in žena deležna stvarnikovega blagoslova: »Plodita se in se množita, napolnita zemljo in si jo podvrzita; gospodujta ribam morja in pticam neba in vsem živim bitjem, ki se gibljejo na zemlji! [...] Glejta, dal sem vama vse rastlinje, ki rodi seme po vsej zemlji, in vse drevje, na katerem je drevesni sad, ki rodi seme. Naj vama bo v živež.«(1 Mz 1,28-29)

Glavni motiv sedmega, zadnjega dne stvarjenja je stvarnikovo zadovoljstvo nad ustvarjenim stvarstvom. V opisih stvarjenjskih dejanj posameznega dne prepoznavamo sekvence, ki zaradi ponavljanja spominjajo na logiko obrednih besedil: »Bog je rekel [...] In zgodilo se je tako [...] Bog je videl, da je dobro.«V njih ni mogoče spregledati želje sestavljavcev oziroma redaktorjev obravnavanega besedila, da bi karseda nedvoumno prikazali popolno skladnost stvarstva s stvarnikovo zamislijo. Stvarnikov počitek sedmega dne (1 Mz 2,1-3) moremo tako razumeti kot končno potrditev te skladnosti in hkrati prepustitev popolne svobode dogajanju v njem.

\section{Prostorske reminiscence v jahvističnem zapisu o stvarjenju}

Starejši jahvistični zapis o stvarjenju po sistematičnosti in logičnosti ne dosega duhovniškega, a zato s stališča pričujočega poskusa ni nič manj zanimiv. Po prepričanju poznavalcev se nam kaže kot amalgam različnih antičnih tradicij (Von Rad 1972, 74), ki so že obstajale davno prej, potem pa jih je Jahvist še domiselno povezal v pričujočo pripoved. Prisotnost prostorskih prvin in način njihove obravnave sta zato še toliko bolj dragocena, saj kažeta, da prostorske podobe kot medij posredovanja zapletenih vsebin o izvoru in smislu sveta ter človeka v njem niso bile domena zgolj intelektualne (duhovniške) elite, temveč so bile globoko zasidrane tudi v najbolj preprosti človeški naravi. 
Prva prostorska podoba, s katero nam postreže jahvist, je pusto, prazno in močvirnato kopno (1 Mz 2,4b-6). Skoraj si ni mogoče predstavljati človeku bolj tujega in neprijaznega okolja. Medtem ko je po duhovniškem zapisu o stvarjenju človek predstavljen kot vrh skrbno zgrajene piramide stvarstva, $\mathrm{v}$ jahvistični pripovedi stvarnik v opisanem, človeku povsem neprijaznem prostoru najprej ustvari človeka. Zdi se, kot bi želela pripoved do skrajnosti poudariti prepadno kakovostno razliko med človekom, ki mu je stvarnik »vdahnil v obličje oživljajočega duha" (1 Mz 2,7), in neizoblikovanostjo prostora, $v$ katerem se je človek znašel. Na prvi pogled skoraj nerazumljiva stvarnikova gesta postane ob branju preostalega besedila dramaturško premišljen kontrast, katerega namen je poudariti odličnost stvarjenjskih dejanj, s katerimi stvarnik preoblikuje surovost prostora v idealno okolje človekovega bivanja. Prvi stvarnikov korak v tej smeri je zasaditev vrta v edenu (1 Mz 2,8), kamor je prestavil človeka. Izraz 'éden bi še najbolj ustrezno prevedli kot »blaženost«(Von Rad 1972, 78), kar kaže na rajsko, človeku domala nepredstavljivo kakovost tega prostora.

Medtem ko v duhovniškem zapisu vegetacija v celoti prekrije kopno, je v jahvistični pripovedi rodovitnost zemlje najprej omejena zgolj na edenski vrt. Ta podoba ni daleč od takratnemu človeku dobro poznane blagodejnosti oaz sredi prostrane puščave, pa tudi kultura gojenja skrbno urejenih vrtov je bila na antičnem Vzhodu močno razširjena. Omejitev vegetacije na edenski vrt daje slednjemu v prostorskem pogledu kakovostno edinstvenost $\mathrm{v}$ odnosu do preostalega pustega in praznega sveta. Iz $1 \mathrm{Mz}$ 2,9 izvemo, da bujno zelenje človeku ni zagotavljalo zgolj vsega potrebnega za preživetje, temveč je s tem, ko je bilo "prijetno za pogled«, tešilo tudi njemu lastno potrebo po lepem. S tem pa momenti prostorske ekskluzivnosti edenskega vrta še niso izčrpani. Omeniti je treba vsaj še dva. Prvi se nanaša na "geografsko« lokacijo vrta. V 1 Mz 2,8 preberemo, da ga je stvarnik zasadil "proti vzhodu«. Navedek kliče v spomin skoraj arhetipski simbolizem sonca, močno razvit v egipčanski kulturi, ki s svojo značilno dvojnostjo vzhoda in zahoda v človeku ozavešča razpetost sveta med rojevanje, rastjo oziroma upanjem ter tesnobo razkroja in smrti. Edenski vrt je torej postavljen v območje življenja, upanja in rasti. Drugi moment ekskluzivnosti rajskega vrta pa razberemo v 1 Mz 2,10-14. Besedilo govori o reki, ki izvira v vrtu, teče iz njega in se deli na štiri veletoke: Pišón, Gihón, Tigris in Evfrat. Ne oziraje se na geografsko resničnost vseh štirih rek, o kateri si tudi eksegeti niso povsem enotni (Von Rad 1972, 79), 
je za razumevanje prostorskih karakteristik obravnavanega besedila pomembno predvsem dvoje. Prvič: dejstvo, da reka izvira v edenskem vrtu, tega s hierarhičnega vidika postavlja na dominantno mesto. Drugič: delitev reke na štiri veletoke, ki po predstavah antičnega Hebrejca oživljajo celoten svet (SPJ 2014, 50) (totaliteta števila 4), in pomen vode, poleg sonca druge nenadomestljive nosilke življenja, daje edenskem vrtu status "popka«sveta. Na domala isto idejo naletimo v religiji antične Grčije, kjer je veljalo za središče sveta panhelenistično Apolonovo preročišče v Delfih (1400 pr. Kr.)

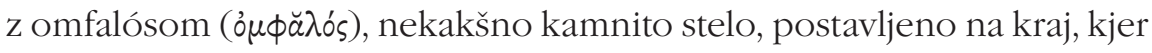
naj bi po mitskem izročilu Apolon premagal kačo, ki je varovala zibelko sveta (Valavanis 2004, 163-169).

Jahvistična pripoved o stvarjenju slika edenski vrt kot prostor človekovega vsestranskega ugodja. S svojim formatom (vrt) ustvarja človeku obvladljivo merilo prostora sredi pustih prostranstev. Je kozmos, umerjen po njegovi meri. S tega vidika so še posebej zanimivi drobci obravnavanega besedila, ki razkrivajo bližino, skoraj intimnost, odnosa med stvarnikom in človekom v tem prostoru. Tako stvarnik ustvarja živa bitja in jih vodi k Adamu, "da bi videl, kako jih bo imenoval, in da bi vsako živo bitje imelo tisto ime, ki bi mu ga dal Adam« (1 Mz 2,19). S poimenovanjem Adam udomači živa bitja in jim da vlogo služenja. V nadaljevanju stvarnik s stvaritvijo Eve preganja njegovo samoto (1 Mz 2,20-22). Prijateljsko bližino med stvarnikom in človekom nakazuje končno tudi 1 Mz 2,25, ko kaže na nemotečo nagoto Adama in Eve; to je izraz intimne povezanosti ob dejstvu stvarnikove navzočnosti (1 Mz 3,8). Na podlagi tu omenjenega pasusa ne gre poenostavljeno zaključevati, da je edenski vrt prikazan kot stvarnikovo bivališče, vsekakor pa je prostor njegove globoke in prosojne povezanosti s človekom. Kot izraz slednje moremo končno videti v edenskem vrtu prisotnost drevesa spoznanja dobrega in hudega (1 Mz 2,8) in s tem čutnozaznavno manifestacijo transcendence, ki je referenčna točka stvarnikovega zagotovila, da človek ne bo nikoli prepuščen samemu sebi. Z drevesom spoznanja dobrega in hudega je povezana tudi edina stvarnikova zahteva do prvega človeka, naj spoštuje njegovo nedotakljivost (1 Mz 2,16-17).

Prav nedotakljivost drevesa spoznanja dobrega in hudega je vzrok za prvi in hkrati usodni človekov spodrsljaj, ki je radikalno spremenil tudi značilnosti prostora. Zapis o dramatičnem preobratu v rajskem vzdušju edenskega vrta najdemo v 1 Mz 3,1-24. Človek se upre edini "prostorski« omejitvi, 
ki je izraz hierarhije v njegovem odnosu s stvarnikom. Ko použije sad prepovedanega drevesa, se edenski vrt spremeni iz prostora sproščenega druženja s stvarnikom v prostor tesnobe in skrivalnic. Adama in Evo postane sram lastne nagote (1 Mz 3,10), v stvarstvu vznikne mehanizem destrukcije. Stvarnik izžene prva človeka iz edenskega vrta. V prostorskem pogledu razširi nedotakljivost prostora od drevesa spoznanja dobrega in hudega na celoten edenski vrt. Radikalnost kakovostnega preobrata pa je v tem, da spoštovanje vzpostavljene nedotakljivosti edenskega vrta ni več stvar človekove svobodne volje, kot je nekdaj veljalo za drevo spoznanja dobrega in hudega, temveč je s strani stvarnika dokončno, saj postavi vzhodno od edenskega vrta »kerube in meč, iz katerega je švigal bliskajoč plamen, da bi stražili pot k drevesu življenja« (1 Mz 3,24). Dokončno kontrastnost kakovosti prostora, $v$ katerega sta bila izgnana prva človeka, $v$ primerjavi s prostorom rajskega vrta vzpostavi stvarnik s prekletstvom: »[N]aj bo zaradi tebe [Adama] prekleta zemlja. V trudu se boš hranil od nje vse dni svojega življenja, trnje in osat ti bo rodila, jedel boš poljsko rastlinje. $V$ potu svojega obraza boš jedel kruh, dokler se ne povrneš v zemljo, kajti iz nje si bil vzet. Zakaj prah si in v prah se povrneš. $(1 \mathrm{Mz} 3,17)$ Vprašanje, ali je mogoče videti v stvarnikovi namestitvi »straže« pred edenski vrt v smeri proti vzhodu upanje na možnost ponovne pripustitve človeka v raj, vsekakor presega zastavljeni poskus. Med simbolnimi prvinami, ki označujejo obravnavani preobrat, je pomenljiv tudi ogenj. Simbolizem ognja v bibličnih besedilih se pojavlja izredno pogosto in je v zvezi z našo razpravo pomenljiv vsaj v treh pomenih: kot označevalec božje navzočnosti, kot stvarnost, po kateri se vzpostavlja nedostopnost in se zato kaže kot učinkovit mehanizem razločevanja, ter končno kot »orodje« prečiščevanja.

\section{Prostorske podobe $v$ pripovedi o vesoljnem potopu}

Proučevanje prostorskih prvin v bibličnih opisih stvarjenja zaokrožuje pripoved o vesoljnem potopu (1 Mz 6,5-9,16). Prekletstvo prostora, v katerega je bil iz edenskega vrta izgnan prvi človek, se kaže v razrasti hudobije in sprijenosti, zaradi katere se stvarnik odloči očistiti stvarstvo. Izbere pravičnega in brezgrajnega Noeta, ki »je hodil z Bogom«(1 Mz 6,9), ter mu naroči, naj si izdela »ladjo iz cipresovega lesa« (1 Mz 6,14). Za to razpravo je zlasti zanimiv opis tega plovila (1 Mz 6,14-16). Izraz se zdi ustreznejši ob dejstvu, da latinski prevod vsebuje izraz arca, kar pomeni »skrinja« (SPJ 
2014, 58). Tudi eksegeti ugotavljajo, da se pojavi na tem mestu uporabljena izvorna hebrejska beseda ta-va v Tori samo še enkrat, in sicer v pripovedi o Mojzesu, ko Levijeva hči naredi košaro iz papirusa, jo premaže z ilovico in smolo, vanjo položi sina Mojzesa in jo skrije v ločje na bregu Nila (2 Mz 2,3). V opisu potopa (1 Mz 6,17-8,14) se pokaže, da je glavni smoter tega plovila ohraniti kal življenja v času vesoljnega očiščenja zemlje s poplavo, ne pa prepeljati Noeta z njegovo družino in predstavniki živih bitij na neki vnaprej določen kraj, čemur načeloma služi ladja. A vrnimo se k plovilu. V citiranem opisu se pokaže, da sta njegova zasnova in oblika stvarnikova zamisel. Izraz slednje je mogoče prepoznavati v domišljeni (popolni) kompoziciji plovila, ki mu daje značaj arhitekture. V besedilu je plovilo naslikano s podobo mogočne skrinje, katere širina znaša 50 komolcev, dolžina 300 komolcev in višina 30 komolcev. Z arhitekturnega stališča je zanimivo že njeno tlorisno razmerje $50: 300$, enako razmerju 1 : 6, iz česar je mogoče sklepati, da sestavlja plovilo šest prostorskih modulov s kvadratno talno ploskvijo dimenzij 50 x 50 komolcev in višino 30 komolcev (risba 2). Oporo tej kompozicijski logiki bi lahko videli tudi v božjem navodilu Noetu, naj naredi »ladjo s prekati« (1 Mz 6,14). Število šest bi lahko bilo ostanek sumerske in babilonske kulture, ki so jo pisci oziroma redaktorji bibličnih besedil nedvomno poznali. Ena od »numeričnih« značilnosti omenjenih kultur je bila namreč uporaba šestdesetinskega sistema, na zahodu ohranjenega še danes v stopinjski delitvi kroga in merjenju časa (Hill 2003, 240-241). Kompozicijsko domišljenost pa daje plovilu zasnova njegove čelne ploskve. Iz dimenzij, navedenih v besedilu, vidimo, da gre za razmerje stranic $3: 5$. V arhitekturni kompoziciji pa tudi v umetniškem ustvarjanju nasploh ima to razmerje posebno mesto. Gre namreč za z malimi celimi števili izraženo razmerje, poznano pod imenom zlati rez oziroma auron (Kurent 2002, 57). Pomena prisotnosti zlatega reza v kompoziciji Noetovega plovila ne gre povezovati zgolj z njegovim estetskim učinkom, ki ga ustvarja z edinstveno učinkujočo medsebojno ubranostjo dveh kompozicijskih prvin, temveč tudi z dejstvom, da se zlati rez, poleg na primer fibonacci-jevega zaporedja, kaže kot eden najširše prisotnih kompozicijskih ključev v stvarstvu kot celoti. Zlati rez so pri snovanju sakralne arhitekture uporabljali že Egipčani. V njegovem ključu je oblikovan na primer profil Kufujeve piramide, raziskovalci pa ga odkrivajo tudi v kompoziciji piramidnega kompleksa v Gizi. Čeprav dobi to ekskluzivno ime šele v devetnajstem stoletju, se je z matematično obdelavo tega proporcijskega ključa ukvarjal že Pitagora, slavni grški kipar 
Fidija (500-432 pr. Kr.) pa ga je uporabil pri zasnovi atenskega Partenona. S tremi moduli višine je usklajen tudi notranji etažni ustroj skrinje. Njeno trodelnost nekateri raziskovalci povezujejo s trodelnostjo že omenjenega hebrejskega pojmovanja kozmosa (Gooder 2005, 38).

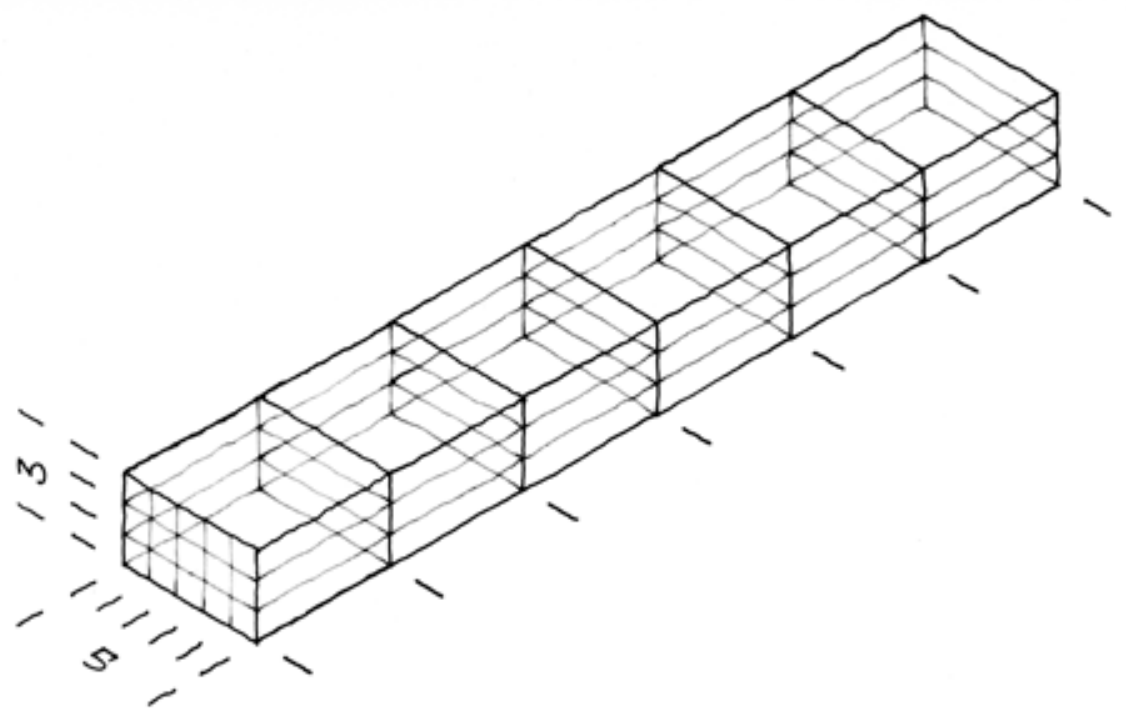

Risba 2

V opisanih kompozicijskih kvalitetah skrinji podobnega plovila ni težko prepoznati stvarnikove vsemogočnosti, s katero se je odločil zaščititi brezgrajno življenje pred popolnim uničenjem. Končno je skrinja tudi izraz celostnosti, saj je prostor, v katerem je varno shranjeno reproduktivno jedro »vsega, kar živi« (1 Mz 6,19). V bibličnem zapisu o Noetovih pripravah na potop smo prvič po "Adamovem grehu« priča ponovnemu intimnemu sožitju med stvarnikom in človekom. Stvarnik predstavi človeku »arhitekturno« zamisel plovila, Noe jo uresniči. Rezultat je nov prostor božje milosti, v katerem se bo človek soočil z apokaliptičnim uničenjem stvarstva. To soočenje bo za Noeta in življenje v plavajočem »kontejnerju «varno, saj je sam Stvarnik, potem ko se je Noe s svojo družino in predstavniki vseh živih bitij vkrcal v plovilo ter preden je kaos preplavil kozmos, "zaprl vrata za njim« (1 Mz 7,16). Ker stvarnik z Noetovo ladjo zagotavlja varnost življenja, jo lahko vidimo kot arhitekturni približek edenskega vrta, saj se bo po potopu iz te skrinje, podobno kot v edenskem vrtu izvirajoča reka vir življenja na zemlji (1 Mz 2,10), razlilo življenje po celotnem novem 
stvarstvu (1 Mz 8,16-17). Novo stvarstvo je oprano zla pa tudi prekletstva. Stvarnik ga izroči Noetu in ga blagoslovi. Prostor novega stvarstva tako dobi novo kakovost, kakovost blagoslovljenosti in upanja (SPJ 2014, 60). Kljub blagoslovljenosti pa to stvarstvo nima več kakovosti edenskega vrta, v katerem se je človek družil s stvarnikom, ki je »ob dnevnem vetriču« (1 Mz 3,8) hodil po njem. V prostoru novega stvarstva opazimo odsotnost pomembne »referenčne točke« Stvarnikove bližine in zaupljivosti do človeka, izraženih v drevesu spoznanja dobrega in hudega. Prepoved, ki se v edenskem vrtu nanaša na uživanje sadu tega drevesa (1 Mz 2,16-17), ostaja tudi v stvarstvu po potopu, celo $\mathrm{v}$ domala nespremenjeni formulaciji, a $\mathrm{z}$ drugo vsebino: »Vse, kar se giblje, kar živi, naj vam bo v živež. Tudi zeleno rastlinje vam dam. Samo mesa z oživljajočo krvjo ne jejte. Tudi za vašo kri, ki daje življenje, bom terjal zadoščenje.» (1 Mz 9,3-5) Človek je torej v novem stvarstvu, ki mu je dano v gospodovanje (1 Mz 9,2.7), postavljen pred izziv vzpostavljanja ter ohranjanja harmoničnosti v svojem odnosu do stvarstva, predvsem pa v odnosu do sočloveka, ob katerem more računati na stvarnikov blagoslov in bližino.

\section{Arhitekturne arhetipske prvine sakralnega v prostorskih podobah pripovedi o stvarjenju}

Potem ko smo iz bibličnih besedil o stvarjenju izluščili prostorske podobe in na kratko orisali njihove značilnosti, se samo po sebi postavlja vprašanje, ali se v njih kažejo vsaj nekatere arhitekturne arhetipske prvine, po katerih more človek, ujet v koordinate čutno-zaznavnega, izkusiti drobce transcendentne realnosti. Pričakovanje je toliko bolj upravičeno zaradi dejstva, da so biblična besedila že sama po sebi zastavljena kot božje razodetje človeku. Arhitekturni arhetipi so kot rezultat primerjalne arhitekturne analize sakralnih kompleksov v uvodoma omenjenem modelu arhitekturne arhetipske matrice strukturirani v tri sklope: v sklop arhetipov, ki določajo prostorske ovoje, sklop arhetipov, ki določajo posebnosti razmejitev oziroma povezav med prostorskimi ovoji, ter sklop arhetipov, ki določajo edinstvenost razmerij med njimi (Debevec 2011, 210). Čeprav se obravnavana besedila v pretežni meri nanašajo na vzpostavljanje stvarstva kot najširšega okvira človekovega odnosa s transcendenco, pokaže soočenje modela s predstavljenimi prostorskimi podobami prisotnost nekaterih arhitekturnih arhetipov. 
Na prvega napeljuje že izpostavljena popolna skladnost med stvarnikovo zamislijo stvarstva in njeno uresničitvijo, poudarjeno v duhovniškem zapisu o stvarjenju. Prvotno stvarstvo se kaže kot sveti prostor, a ne na način, da bi bil ta edinstveni »čas-prostor-materija« sam po sebi nosilec svetosti, temveč zaradi njegove uglašenosti s stvarnikovo zamislijo, v katero človekova »roka«kot princip preoblikovanja še ni posegla. Priča smo najmonumentalnejši prostorski interpretaciji arhetipa »sveto«(Debevec 2011, 218).

Jahvistični zapis o stvarjenju pa vnaša s podobo edenskega vrta v prostor prvotnega stvarstva že prvo strukturiranost. Znotraj prej omenjenega arhetipskega prostorskega ovoja »sveto« je z edenskim vrtom vzpostavljen nov arhetipski prostorski ovoj "presveto«, saj je v besedilih naslikan kot prostor človekovega sobivanja s stvarnikom. S tem pa nabor arhetipov, ki jih moremo razbrati iz zapisov o edenskem vrtu, še ni izčrpan. Zadnjega med arhetipskimi prostorskimi ovoji določa/ta drevo/drevesi življenja ter spoznanja dobrega in hudega (1 Mz 2,9). Po svoji naravi ustreza arhetipskemu prostorskemu ovoju, imenovanemu »lik transcendence«. Človekova samovolja v odnosu do stvarnikove vzpostavitve prostorske strukture edenskega vrta povzroči uveljavitev »oboda« kot arhetipa iz sklopa arhetipskih povezav oziroma razmejitev med prostorskimi ovoji. Obod okrog edenskega vrta sicer v pripovedi o človekovem padcu ni neposredno omenjen, a ga je mogoče prepoznati v podobah kerubov, meča in plamenov, ki so varovali pot do drevesa življenja. V besedilu opisana postavitev kerubov napeljuje na motiv prehoda v obodu, saj je ta vedno posebej občutljivo mesto prekinitve in zato potreben posebne zaščite. V opisani novi ureditvi stvarstva se kažejo še vsaj trije arhitekturni arhetipi iz skupine tistih, ki določajo posebnosti v odnosih med prostorskimi ovoji in razmejitvami. Prvi tak arhetip je »selektivnost dostopnosti«. Če je pred človekovim padcem zgolj enostopenjska in se kaže na relaciji edenski vrt-prepovedano/i drevo/ drevesi, je po njem okrepljena s še eno stopnjo, saj je selektivnost dostopnosti vzpostavljena tudi na relaciji »stvarstvo«-edenski vrt. Drugi arhetip, soroden pravkar obravnavanemu, je »hierarhičnost«. Vzpostavlja jo že opisana posebnost samega edenskega vrta pa tudi njegov privilegirani položaj na zemlji, kakršna je na primer njegova »višinska« izpostavljenost oziroma dejstvo, da v njem izvira reka, iz katere se preko štirih veletokov napaja celotna zemlja. Najvišje mesto $v$ hierarhiji edenskega vrta pripada drevesu/drevesoma, ki jima je dal stvarnik zrasti »sredi vrta«(1 Mz 2,9). Zadnji arhitekturni arhetip sakralnega, ki ga razbiramo $\mathrm{v}$ prostorski podobi 
edenskega vrta, je »orientacija«. Namig zanj najdemo v obravnavanih besedilih na dveh mestih. V 1 Mz 2,8 preberemo, da je "Gospod Bog zasadil vrt v ednu proti vzhodu«, v 1 Mz 4,24 pa izvemo, da je Stvarnik ob izgonu Adama iz raja postavil angelsko stražo »vzhodno od edenskega vrta«, da bi stražila "pot k drevesu življenja«. Izpostavljeni drobci napeljujejo na smer vzhod-zahod kot glavno orientacijsko os rajskega vrta. Glede na to, da analizirana besedila obravnavajo problem izvora kozmosa, njegove ureditve in mesta človeka v njem, je razumljivo, da se v interpretacijah arhitekturnih arhetipov sakralnega pojavljajo nearhitekturni naravni pojavi, kot so stvarstvo, smeri neba, reka, bujnost vegetacije oziroma drevo in ogenj. Izjemoma je ob zagotavljanju nedotakljivosti edenskega vrta uporabljena podoba transcendentne realnosti (kerubi). V tem pogledu pa pomeni zapis o Noetovem podvigu pomemben premik k uporabi arhitekturnih prvin v interpretacijah arhetipov sakralnega. Biblično besedilo o gradnji Noetovega plovila nam najprej postreže z dvema dodatnima arhitekturnima arhetipoma sakralnega. Prvi spada v sklop povezav in razmejitev, imenovan »arhitekturna lupina« (Debevec 2011, 226). V primeru Noetovega plovila ima to funkcijo obod skrinje, saj z vseh strani ovija dragoceno, od stvarnika odbrano življenje in ga v času vesoljnega potopa varuje pred razbesnelimi silami kaosa. Zadnji arhitekturni arhetip sakralnega v našem prikazu pa je »odličnost«. Na nekatere namige na arhetip odličnosti naletimo tudi v drugih obravnavanih besedilih. Tako moremo s tem arhetipom povezati stvarnikovo zadovoljstvo nad šestdnevnimi stvarjenjskimi dejanji, ko je "videl vse, kar je naredil, in glej, bilo je prav dobro« (1 Mz 2,31), ali pa nad podobo vrta kot zgledno kultivirano naravo, "prijetno za pogled « (1 Mz 2,9). V bibličnem besedilu o Noetovih pripravah na potop pa je arhetip odličnosti zastopan $\mathrm{v}$ vseh treh lastnostih dobre arhitekture, ki jih je že rimski antični arhitekt Vitruvij ( 80- 15 pr. Kr.) formuliral v domala večno veljavni trojici trdnosti (firmitas), uporabnosti (utilitas) in lepote (venustas). Cipresov les in predalčna konstrukcija (notranja delitev na nadstropja) sta plovilu zagotavljala trdnost (1 Mz 6,14). Ključni pogoji funkcionalnosti podviga so bili plovnost, z njo povezana vodotesnost in ustrezna prostornost, da bi lahko sprejela odbrano življenje. Noe je ladjo zasmolil z zunanje in notranje strani ter s tem zagotovil varnost bivanja v njej (1 Mz 6,14). Odličnost plovila po estetski plati dokazuje najprej dejstvo, da je zamisel Stvarnikova (1 Mz 6,15). Njena estetska dovršenost pa je še dodatno poudarjena s predstavitvijo njene kompozicijske zasnove, pri kateri je bil kot kompozicijski ključ uporabljen prestižen zlati rez. 


\section{Sklep}

Analiza obravnavanih svetopisemskih besedil potrjuje tezo o prisotnosti prostorskih podob. Še več, kaže na njihovo presenetljivo bogastvo. Očitno je, da so se sestavljavcem in redaktorjem teh starodavnih besedil prostorske podobe zdele učinkovita preobleka, zaradi katere so postali razmisleki o nastanku sveta in človekove vloge v njem človeku bližji in lažje razumljivi. Čeprav v obravnavanih besedilih prevladujejo prostorske podobe iz narave, kar je razumljivo glede na "predcivilizacijsko« tematiko, ki jo besedila obravnavajo, pa v njih najdemo tudi prve in zato zelo dragocene arhitekturne poteze. Njihov pomen in vključenost $\mathrm{v}$ prostorsko matrico, $\mathrm{v}$ katero je vpeto Sveto pismo kot celota, lahko na tem mestu zgolj slutimo, saj $\mathrm{v}$ raziskavi izpostavljene prostorske podobe razpirajo celo vrsto zanimivih vprašanj: o njihovi avtentičnosti oziroma kulturnih vplivih, ki so v njih pustili svoje sledi, o njihovih simbolnih horizontih ter zlasti o njihovem "vplivnem območju «notraj celotnega fonda bibličnih besedil. Slednje ostaja izziv nadaljnjega raziskovanja. Pavel je na atenskem Areopagu poganskim Atencem, vajenim arhitekturnega razkošja, spregovoril o njim neznanem Bogu, ki je, kot pravi, »napolnil vse obličje zemlje in ljudem odmeril čase in meje bivanja, da bi Boga iskali in se morda do njega dotipali in ga našli, saj ni daleč od nikogar izmed nas. Zakaj v njem živimo, se gibljemo in smo." (Apd 17,22-28) Tako je hote ali nehote pokazal na dragocenost prostora, ki je po besedah Galilea Galileja druga biblija in ga Bog podarja človeku, da bi se mu po njem lahko približal (Norman 1990, 176). 


\section{Reference}

Arnheim, Rudolf. 1977. The Dynamics of Architectural Form. Berkeley-Los Angeles - London: University of California Press.

Bouleau, Charles. 1963. La géomètrie secrète des peintres. Paris: Éditions de Seuil.

Butina, Milan. 1982. Elementi likovne prakse. Ljubljana: Mladinska knjiga.

Collins, J.John. 2004. Israel (Histories). V: Religions of the Ancient World, 181188. Cambridge: The Belknap Press of Harvard University Press.

Debevec, Leon. 2011. Arhitekturni obrisi sakralnega. Ljubljana: Inštitut za sakralno arhitekturo in Teološka fakulteta Univerze v Ljubljani.

Debevec, Leon. 2013. Arhitekturne poti h krščanski edinosti. V: Edinost in dialog 68: 41-57.

Gooder, Paula. 2005. The Pentateuch: A Story of Beginnings. S.n.: T\&T Clark.

Heschel, Abraham Joshua. 2013. Sobota, gospodov dan. Ljubljana: Družina.

Knight, Douglas A. 1990. Cosmology. V: Watson E. Mills, ur., Mercer Dictionary of the Bible. Macon, Georgia: Mercer University Press.
Kurent, Tine. 2002. Arhitektov zvezek. Ljubljana: Nuit.

Muhovič,Jožef. 1996. Koralni preludij o naravi prostora. Esej o ontologiji / Prelude Chorale on the Nature of Space. Essay on the Ontology. V: Arhitektov bilten, 131-132, 70-75, 100-104.

Muhovič, Jožef. 2015. Leksikon likovne teorije. Celje: Celjska Mohorjeva družba.

McGraw-Hill. 2007. Encyclopedia of Science E Technology. New York: McGraw-Hill.

Norman, Edward. 1990. The House of God. London: Thames and Hudson.

Olyan, M. Saul. 2004. Sacred times and spaces - Israel. V: Religions of the Ancient World, 256-259. Cambridge: The Belknap Press of Harvard University Press.

SPJ. 2014. Ljubljana: Družina, TEOF in Slovenska škofovska konferenca.

Valavanis, Panos. 2004. Games and Sanctuaries in Ancient Greece. Los Angeles: Getty Publications.

Von Rad, Gerhard. 1972. Genesis. London: SCM Press Ltd.

Von Rad, Gerhard. 1979. Old Testament Theology. London: SCM Press Ltd. 